\title{
Pseudomonas brassicacearum sp. nov. and Pseudomonas thivervalensis sp. nov., two root-associated bacteria isolated from Brassica napus and Arabidopsis thaliana
}

\author{
Wafa Achouak, ${ }^{1}$ Laurent Sutra, ${ }^{2}$ Thierry Heulin, ${ }^{1}$ Jean-Marie Meyer, ${ }^{3}$ \\ Nathalie Fromin, ${ }^{1}$ Sylvie Degraeve, ${ }^{1}$ Richard Christen ${ }^{4}$ and Louis Gardan ${ }^{2}$
}

Author for correspondence: Wafa Achouak. Tel: +33442 2549 61. Fax: +33442256648. e-mail:wachouak@cea.fr

1 CEA/Cadarache, DSV-DEVM, Laboratoire d'Ecologie Microbienne de la Rhizosphère, UMR 163 CNRS-CEA, F-13108 SaintPaul-lez-Durance, France

2 Institut National de la Recherche Agronomique, Station de Pathologie Végétale et Phytobactériologie, 49071 Beaucouzé cedex, France

3 Laboratoire de Microbiologie et de Génétique, UPRES A-7010, Institut de Botanique, 67083 Strasbourg, France

4 ESA 7076 Université Pierre et Marie Curie et CNRS, Observatoire Océanologique, Station Zoologique, F-06230 Villefranche-sur-mer, France

\begin{abstract}
Bacteria isolates phenotypically related to Pseudomonas corrugata have frequently been isolated from the rhizosphere of Arabidopsis thaliana and Brassica napus grown on different soils. 16S rDNA (rrs) gene sequencing, DNA-DNA hybridization, biochemical characterization and siderophore typing showed that these isolates belong to two different species that are distinct from other species of the genus Pseudomonas, including $P$. corrugata. A description of properties of these two new species is given based on the study of 16 isolates. Proposed names are Pseudomonas brassicacearum (10 strains studied) and Pseudomonas thivervalensis (6 strains studied). The type strain of Pseudomonas brassicacearum is CFBP $11706^{\top}$ and that of Pseudomonas thivervalensis is CFBP 11261 .
\end{abstract}

Keywords: Pseudomonas brassicacearum sp. nov., Pseudomonas thivervalensis sp. nov., Arabidopsis thaliana, Brassica napus, polyphasic taxonomy

\section{INTRODUCTION}

The genus Pseudomonas formerly consisted of phylogenetically unrelated groups of proteobacteria including more than 100 validly described species (Palleroni, 1984; Skerman et al., 1989). rRNA-DNA hybridization allowed the genus to be subdivided into five rRNA groups I-V (Palleroni et al., 1973). Kersters et al. (1996) have summarized the recent changes in the classification of the former Pseudomonas species, which are now classified in about 15 genera belonging to the $\alpha, \beta$ and $\gamma$ subclasses of Proteobacteria. The species belonging to the genus Pseudomonas sensu stricto are now restricted to the rRNA similarity group I of Palleroni (1984), which belongs to the $\gamma$ subclass

Abbreviations: ARDRA, amplified rDNA restriction analysis; IEF, isoelectric focusing; $\mathrm{pl}$, isoelectric values.

The GenBank/EMBL/DDBJ accession numbers for the rrs gene sequences in this paper are AF100321-AF100323. of Proteobacteria. The rrs gene sequences of strains isolated from different environments suggest that taxonomic studies might reveal new Pseudomonas species (Behrendt et al., 1999; Boivin-Jahns et al., 1995; Whyte et al., 1997; Wilson et al., 1996).

Pseudomonas species are frequently isolated from different ecological niches, where some may act as pathogens of animals, plants or fungi and some are beneficial free-living soil bacteria referred to as plantgrowth-promoting rhizobacteria. They are also frequently isolated from polluted sites containing high levels of pollutants such as heavy metals, polychlorinated compounds and polyaromatic hydrocarbons.

Two groups of strains related to Pseudomonas corrugata were isolated from the rhizoplane of Arabidopsis thaliana and Brassica napus growing in different soils. To describe the intraspecific diversity of these populations and subsequently to study the molecular interactions between A. thaliana and these bacteria, a 
Table 1. Strains used in this study

Abbreviations: CFBP, Collection Française de Bactéries Phytopathogènes, Angers, France; IS, isolated strains; NT, not tested in numerical taxonomy.

\begin{tabular}{|c|c|c|c|c|c|c|}
\hline Taxon & Strain & $\begin{array}{c}\text { Other } \\
\text { designation }\end{array}$ & Source of isolation* & Phenon & Subphenon & $\begin{array}{l}\text { Accession } \\
\text { no. }\end{array}$ \\
\hline P. brassicacearum & CFBP 11874 & NFM421 & A. thaliana & 1 & $1 \mathrm{c}$ & AF100322 $\dagger$ \\
\hline P. brassicacearum & CFBP 11875 & NFM999 & A. thatiana & 1 & $1 \mathrm{c}$ & \\
\hline P. brassicacearum & CFBP 11862 & NFM001 & A. thaliana & 1 & $1 \mathrm{c}$ & \\
\hline P. brassicacearum & CFBP 11264 & DBS11 & B. napus & 1 & 1a & \\
\hline P. brassicacearum & CFBP 11711 & DBS16 & B. napus & 1 & $1 \mathrm{a}$ & \\
\hline P. brassicacearum & CFBP 11267 & ABS1 & B. napus & 1 & 1a & \\
\hline P. brassicacearum & CFBP 11268 & D5K 12 & B. napus & 1 & 1a & \\
\hline P. brassicacearum & CFBP 11700 & ABS2 & B. napus & 1 & 1a & \\
\hline P. brassicacearum & CFBP 11699 & A5K3 & B. napus & 1 & 1a & \\
\hline P. brassicacearum & CFBP $11706^{\mathrm{T}}$ & $\mathrm{DBK} 11^{\mathrm{T}}$ & B. napus & 1 & 1a & AF100321 $\dagger$ \\
\hline P. thivervalensis & CFBP 11866 & MLG19 & A. thaliana & 1 & $1 b$ & \\
\hline P. thivervalensis & CFBP 11864 & MLG6 & A. thaliana & 1 & $1 b$ & \\
\hline P. thivervalensis & CFBP 11863 & MLG3 & A. thaliana & 1 & $1 \mathrm{~b}$ & \\
\hline P. thivervalensis & CFBP 11867 & MLG39 & A. thaliana & 1 & $1 \mathrm{~b}$ & \\
\hline P. thivervalensis & CFBP 11865 & MLG14 & A. thaliana & 1 & $1 b$ & \\
\hline P. thivervalensis & CFBP $11261^{\mathrm{T}}$ & SBK $26^{\mathrm{T}}$ & B. napus & 1 & $1 b$ & AF100323 \\
\hline P. corrugata & CFBP 10146 & & Lycopersicon esculentum & 2 & & \\
\hline P. corrugata & CFBP 10883 & & Lycopersicon esculentum & 2 & & \\
\hline P. corrugata & CFBP 10904 & & Lycopersicon esculentum & 2 & & \\
\hline P. corrugata & CFBP $2431^{\mathrm{T}}$ & ATCC $29736^{\mathrm{T}}$ & Lycopersicon esculentum & 2 & & D84012† \\
\hline P. fluorescens biovar II & CFBP 2125 & ATCC 17482 & & 3 & & \\
\hline P. fluorescens biovar IV & CFBP 3150 & ATCC 12983 & Soil & 3 & & \\
\hline P. fluorescens biovar IV & CFBP 2129 & ATCC 17513 & Water & 3 & & \\
\hline 'P. blatchfordae' & CFBP 3280 & ATCC $9446^{\mathrm{T}}$ & Phaseolus vulgaris & 4 & & \\
\hline P. fluorescens biovar I & CFBP $2102^{\mathrm{T}}$ & IAM $12022^{\mathrm{T}}$ & Water reservoir & 4 & & D84013\$ \\
\hline Pseudomonas. sp. & CFBP 2022 & & Allium sativum & 4 & & \\
\hline P. marginalis pv. alfalfae & CFBP 2039 & NCPPB 2644 & Medicago sativa & 5 & & \\
\hline P. marginalis pv. pastinacea & CFBP 2038 & ATCC 13889 & Pastinacea sativa & 5 & & \\
\hline P. marginalis pv. marginalis & CFBP 3153 & ATCC 17819 & Pleural fluid & 5 & & \\
\hline P. fluorescens biovar I & CFBP 2123 & ATCC 17397 & Tap water & 6 & & \\
\hline P. putida biotype B & CFBP $3140 t 1$ & ATCC 17430 & Unknown & 6 & & \\
\hline P. aureofaciens & CFBP $3155 \mathrm{t} 1$ & ATCC 17415 & Soil & IS & & \\
\hline P. asplenii & CFBP $3279^{\mathrm{T}}$ & LMG $2173^{\mathrm{T}}$ & Asplenium nidus & IS & & $\mathrm{Z76655}$ \\
\hline P. corrugata & $2140 \S$ & & Wheat rhizosphere & IS & & \\
\hline ' $P$. gingeri' & CFB2810 & LMG 5327 & Agaricus bisporus & IS & & \\
\hline P. tolaasii & CFBP $2068^{\mathrm{T}}$ & ATCC $33618^{\mathrm{T}}$ & Agaricus bisporus & IS & & D84028t \\
\hline P. aureofaciens & CFBP $2133^{\mathrm{T}}$ & DSM $6698^{\mathrm{T}}$ & Clay in kerosene & IS & & $\mathrm{Z} 76656 \%$ \\
\hline P. chlororaphis & CFBP $2132^{\mathrm{T}}$ & LMG $5004^{\mathrm{T}}$ & Plate contaminant & IS & & $\mathrm{Z76657+}$ \\
\hline P. aeruginosa & CFBP $2466^{\mathrm{T}}$ & LMG $1242^{\mathrm{T}}$ & Unknown & IS & & Z76651: \\
\hline P. fluorescens biovar $\mathrm{V}$ & CFBP 2130 & ATCC 17386 & Water & IS & & \\
\hline P. fluorescens biovar III & CFBP 3149 & ATCC 17559 & Unknown & IS & & \\
\hline P. caricapapayae & CFBP $3204^{\mathrm{T}}$ & ATCC $33615^{\mathrm{T}}$ & Carica papaya & IS & & D84010t \\
\hline P. cichorii & CFBP $2101^{\mathrm{T}}$ & LMG $2162^{\mathrm{T}}$ & Cichorium endivia & IS & & Z76658 \\
\hline P. putida biotype A & CFBP $2066^{\mathrm{T}}$ & ATCC $12633^{\mathrm{T}}$ & Soil & IS & & \\
\hline P. putida biotype A & CFBP $3142 \mathrm{t} 1$ & & Unknown & IS & & \\
\hline P. putida biotype A & CFBP $3143 \mathrm{t} 2$ & & Unknown & IS & & \\
\hline P. fuscovaginae & CFBP $2065^{\mathrm{T}}$ & NCPPB $2289^{\mathrm{T}}$ & Oryza sativa & IS & & \\
\hline P. agarici & CFBP $2063^{\mathrm{T}}$ & LMG $2112^{\mathrm{T}}$ & Agaricus bisporus & IS & & $\mathrm{Z76652}$ : \\
\hline P. flectens & CFBP $3281^{\mathrm{T}}$ & ATCC $12775^{\mathrm{T}}$ & Phaseolus vulgaris & IS & & \\
\hline P. marginalis pv. marginalis & CFBP $1387^{\mathrm{T}}$ & LMG $2210^{\mathrm{T}}$ & Cichorium intybus & NT & & Z76663: \\
\hline Genomospecies FP1 & CFBP $10529^{\mathrm{T}}$ & & Lycopersicon esculentum & NT & & \\
\hline Genomospecies FP2 & CFBP $10530^{\mathrm{T}}$ & & Lycopersicon esculentum & NT & & \\
\hline Genomospecies FP3 & CFBP $10569^{T}$ & & Lycopersicon esculentum & NT & & \\
\hline
\end{tabular}

* A. thaliana rhizoplane isolates were from plants growing in soils from Thiverval-Grignon, France (MLG series) or Méréville, France (NFM series). B. napus rhizoplane isolates were from plants growing in soils from Dieulouard, France (DB and D5 series), Andilly, France (AB and A5 series), Sexey-les-Bois, France (SBK26 ${ }^{\mathrm{T}}$ ).

$\dagger \mathrm{EMBL} /$ GenBank/DDBJ accession number of sequences from this study.

$\$$ EMBL/GenBank/DDBJ accession number of retrieved sequences.

§ Provided by M. H. Ryder, CSIRO Land and Water, PMB 2, Glen Osmond 5064, South Australia. 
polyphasic taxonomy was necessary. Here, the description of two new Pseudomonas species is reported, for which the names Pseudomonas brassicacearum sp. nov. and Pseudomonas thivervalensis sp. nov. are proposed.

\section{METHODS}

Bacterial strains and culture conditions. In total, 53 strains were studied (Table 1). A total of 16 strains was isolated, eight from the rhizosphere of Brassica napus cv. Brutor grown in three soils (Andilly, Sexey-les-Bois and Dieulouard, France) and eight from that of Arabidopsis thaliana ecotype WS grown in two soils (Thiverval-Grignon and Méréville, France). Plants were grown in pots and incubated in a greenhouse for 3 weeks (B. napus) or 6 weeks (A. thaliana). These bacteria were isolated from plant rhizoplane as previously described (Mavingui et al., 1992). A semi-selective medium derived from that of Gould et al. (1985) was used for the isolation of strains from A. thaliana rhizoplane. This modified medium (RCS) contained mineral solution RCV (Heulin et al., 1987) supplemented with Casamino acids (5 g $\left.\mathrm{1}^{-1}\right)$, sodium lauroyl sarcosinate $\left(1 \cdot 2 \mathrm{~g} \mathrm{l}^{-1}\right)$, sucrose $\left(20 \mathrm{~g} \mathrm{l}^{-1}\right)$ and agar $\left(15 \mathrm{~g} \mathrm{l}^{-1}\right)$. For strains isolated from $B$. napus rhizoplane, mineral solution RCV supplemented with sucrose $\left(20 \mathrm{~g} \mathrm{l}^{-1}\right)$ and agar $\left(15 \mathrm{~g} \mathrm{l}^{-1}\right)$ was used. These strains represented up to $10 \%$ of the total cultivable microflora associated with $A$. thaliana roots, and up to $60 \%$ of that associated with $B$. napus roots. Thirty-seven identified Pseudomonas strains, including 18 type strains, were used as references in the numerical taxonomy and for DNA-DNA hybridization. Strains were grown in tryptic soy broth (TSB; Difco) medium at $28^{\circ} \mathrm{C}$. They were grown for $48 \mathrm{~h}$ for DNA extraction and up to $\mathrm{OD}_{590} 0.5$ for PCR amplification. All the strains were maintained on tenfold diluted tryptic soy agar (TSA).

Conventional tests. The presence of oxidase, gelatinase and arginine dihydrolase activities, production of fluorescent pigment on King B medium, levan formation, acidification of sucrose, sorbitol, erythritol and mannitol, reduction of nitrate, hydrolysis of Tween 80 and aesculin, and the hypersensitivity reaction on tobacco leaves were tested as described by Leliott et al. (1966). Pectinolytic activity was tested by the method of Prunier \& Kaiser (1964) and Hildebrand (1971). Utilization of lactate, $L(+)$-tartrate and $\mathrm{D}(-)$-tartrate was tested on the basal medium of Ayers et al. (1919) supplemented with $0 \cdot 1 \%(\mathrm{w} / \mathrm{v})$ organic acid sodium salts. The presence of DNase was tested on DNA agar (Diagnostic Pasteur). Flagella were stained by the method of Rhodes (1958).

Metabolic profiles. The oxidation of 95 carbon substrates was determined using BIOLOG GN microplates as recommended by the manufacturer. Results were read with an ELISA microplate reader (Dynatech, MR5000) after 24 or $48 \mathrm{~h}$ incubation at $28^{\circ} \mathrm{C}$. Additionally, strains were studied for the assimilation of 99 organic substrates using Biotype 100 strips (bioMérieux) as recommended by the manufacturer. Results were read visually after 2,3 and $4 \mathrm{~d}$ incubation at $26^{\circ} \mathrm{C}$.

Numerical taxonomy. A total of 114 characters, including the results of 19 conventional tests, and 95 oxidation activities obtained with BIOLOG GN microplates were included in the numerical taxonomy analysis. The distance matrix was calculated using the Jaccard coefficient (Sneath \& Sokal,
1973). Cluster analysis was performed using the unweighted pair group method with averages (UPGMA). At a given distance level and for the different phenons, the amount of information for each test was measured by calculating the coefficient of diagnostic ability to determine the discriminating biochemical characteristics (Descamps \& Véron, 1981).

Determination of the rrs gene sequences. The $r r s$ gene was amplified as described in detail by Achouak et al. (1999). The PCR products from three rhizoplane strains (CFBP $11706^{\mathrm{T}}$, CFBP 11874 and CFBP $11261^{\mathrm{T}}$ ) were purified on a $1 \%$ lowmelting-point agarose gel. They were directly sequenced using a protocol described by Anderson et al. (1992) and the sequencing primers as described by Achouak et al. (1999). Sequences were obtained with the Genomyx system (Beckman).

Amplified rDNA restriction analysis (ARDRA). The amplified rrs genes were analysed by restriction digestion with 11 restriction enzymes (AluI, CfoI, DdeI, HinfI, TaqI, HaeIII, $M s p \mathrm{I}, R s a \mathrm{I}, N d e \mathrm{II}, N c i \mathrm{I}$ and $S c r \mathrm{FI})$. The restriction profiles were compared with those of the type strains of related species of Pseudomonas: Pseudomonas agarici, 'Pseudomonas blatchfordae', Pseudomonas flectens, Pseudomonas fluorescens, Pseudomonas fuscovaginae, Pseudomonas marginalis (data from this work, Table 1); and Pseudomonas aeruginosa, Pseudomonas alcaligenes, Pseudomonas aureofaciens, Pseudomonas chlororaphis, Pseudomonas cichorii, $P$. corrugata, P. marginalis, Pseudomonas mendocina, Pseudomonas pseudoalcaligenes, Pseudomonas putida, Pseudomonas stutzeri, Pseudomonas syringae, Pseudomonas tolaasii and Pseudomonas viridiflava (data from Laguerre et al., 1994).

Phylogenetic analysis. The rrs gene sequences from the three rhizoplane strains (CFBP $11706^{\mathrm{T}}$, CFBP 11874 and CFBP $11261^{\mathrm{T}}$ ) were aligned and analysed by comparison with a database of previously aligned sequences (about 10000). Three phylogenetic methods were used to assess the phylogenetic positions of these sequences, a neighbour-joining algorithm according to Saitou \& Nei (1987), maximumlikelihood (options QFYG, FDNAML program of G. J. Olsen, University of Illinois, Urbana, IL, USA) and maximumparsimony (PAUP 3.0s for Macintosh, heuristic search; Swofford, 1990). The robustness of each topology was checked using the neighbour-joining method and 500 bootstrap replications (Kimura two-parameters correction). Trees were drawn using the NJPLOT program for Macintosh (M. Gouy, CNRS UMR 5558, Université Claude Bernard, Lyon, France) and MacDraw software. Domains used to construct the tree shown in Fig. 2 were regions of the rrs gene sequences available for all sequences: positions 49-1317 corresponding to the rrs gene sequence of $P$. corrugata.

DNA-DNA hybridization. Extraction and purification of DNA were performed using previously described methods (Brenner et al., 1982). Native DNAs were labelled in vitro by nick translation with tritium-labelled nucleotides (Amersham). The S1 nuclease-trichloroacetic acid method for hybridization has been previously described (Croza et al., 1973; Grimont et al., 1980). The reassociation temperature was $70^{\circ} \mathrm{C}$. DNA-DNA hybridization tests were carried out using labelled DNA from strains CFBP $11261^{\mathrm{T}}$, CFBP 11699 and $P$. corrugata CFBP $2431^{\mathrm{T}}$. The strains used in DNA-DNA hybridization are listed in Table 3.

Thermal stability of DNA reassociation. The temperature at which $50 \%$ of reassociated DNA became hydrolysable by nuclease $\mathrm{S} 1\left(T_{\mathrm{m}}\right)$ was determined using the method of Croza 


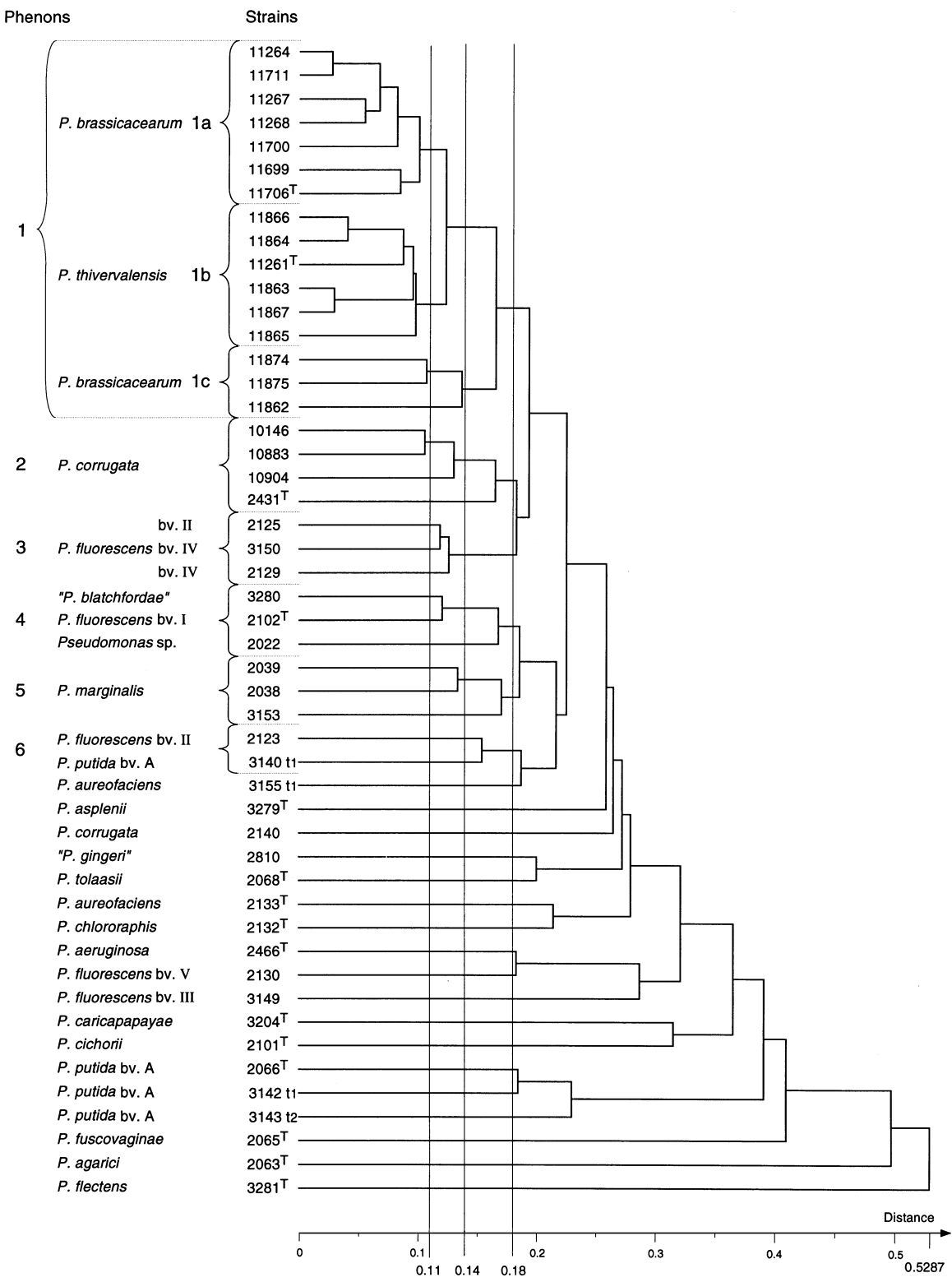

Fig. 1. Dendrogram of phenotypic distances for 49 strains. et al. (1973). The $T_{\mathrm{m}}$ was determined when the percentage of DNA-DNA hybridization was between 50 and $65 \%$.

DNA base composition. The $\mathrm{G}+\mathrm{C}$ contents of strains CFBP 11699 and CFBP $11261^{\mathrm{T}}$ were determined by the thermal denaturation temperature (Marmur \& Doty, 1962) and were calculated using the equation of Owen \& Lapage (1976). Escherichia coli strain K12 CIP 54-117 (DNA G + C content $50.6 \mathrm{~mol} \%$ ) was used as a control.

Electrophoretic characterization of pyoverdines. Pyoverdines produced during growth in CAA medium [containing $\left(1^{-1}\right)$ : Bacto Casamino Acid (Difco), $5 \mathrm{~g} ; \mathrm{K}_{2} \mathrm{HPO}_{4} .3 \mathrm{H}_{2} \mathrm{O}, 1 \cdot 54 \mathrm{~g}$; $\mathrm{MgSO}_{4} \cdot 7 \mathrm{H}_{2} \mathrm{O}, 0.25 \mathrm{~g}$ ] were analysed by isoelectric focusing (IEF) according to Koedam et al. (1994). A Bio-Rad model 111 Mini IEF Cell apparatus was used under electrophoresis conditions as recommended by the manufacturer $(15 \mathrm{~min}$ at $100 \mathrm{~V}, 15 \mathrm{~min}$ at $200 \mathrm{~V}$ and $1 \mathrm{~h}$ at $450 \mathrm{~V}$ ). Polyacrylamide gel (5\%) containing ampholines (Biolyte $3 / 10$ from Bio-Rad) was loaded with $1 \mu 1$ sample of 20 -fold concentrated pyoverdine-containing CAA supernatants. Pyoverdine bands were visualized under UV light and their corresponding isoelectric values ( $\mathrm{pI}$ ) were determined from a standard curve obtained by slicing the gel immediately after electrophoresis into $0.5 \mathrm{~cm}$ bands, which were incubated separately in $2 \mathrm{ml} \mathrm{KCl}$ solution $(10 \mathrm{mM})$ for $30 \mathrm{~min}$ before measuring the $\mathrm{pH}$. Electrophoresis of pyoverdines on Cellogel was performed as previously described (Meyer \& Abdallah, 1978).

\section{RESULTS}

\section{Phenotypic analysis}

The dendrogram showing phenotypic distances between the 49 strains is depicted in Fig. 1. At a distance level of $0 \cdot 18$, six phenons and 18 isolated phenotypes were observed (Table 1). All the strains isolated from the rhizoplane of $B$. napus and $A$. thaliana clustered in phenon 1. At lower distance levels of $0 \cdot 14$ and $0 \cdot 11$, phenon 1 could be subdivided into three subphenons 
Table 2. Phenotypic and biochemical characters that differentiate subphenons $1 \mathrm{a}, 1 \mathrm{~b}$ and $1 \mathrm{c}$ from phenons $2-6$ and from type strains of Pseudomonas species

+ , Positive; -, negative; D, variable (number of positive strains in parentheses).

\begin{tabular}{|c|c|c|c|c|c|c|c|c|c|c|c|c|c|c|c|c|c|c|}
\hline \multirow[t]{2}{*}{ Character } & \multicolumn{8}{|c|}{ Phenon or subphenon no.* } & \multicolumn{10}{|c|}{ Type strains from CFBP collection $\dagger$} \\
\hline & 1a & $1 b$ & $1 \mathrm{c}$ & 2 & 3 & 4 & 5 & 6 & $3279^{\mathrm{T}}$ & $2068^{\mathrm{T}}$ & $2133^{\mathrm{T}}$ & $2132^{\mathrm{T}}$ & $2466^{\mathrm{T}}$ & $2101^{\mathrm{T}}$ & $2066^{\mathrm{T}}$ & $2065^{\mathrm{T}}$ & $2063^{\mathrm{T}}$ & $3281^{\mathrm{T}}$ \\
\hline Production of pyoverdine & + & + & + & - & + & + & + & + & + & + & + & + & + & + & + & + & + & + \\
\hline Levan production & + & + & + & - & $\mathrm{D}(1)$ & $\mathrm{D}(1)$ & + & $\mathrm{D}(1)$ & - & - & + & + & - & - & - & - & - & + \\
\hline DNase & + & + & + & $\mathrm{D}(2)$ & - & D (1) & + & - & - & + & + & + & + & - & - & - & - & - \\
\hline Nitrate reduction & $\mathrm{D}(5)$ & $\mathrm{D}(2)$ & + & + & + & - & + & + & - & - & - & + & + & - & + & - & - & - \\
\hline Gelatin hydrolysis & + & + & + & $\mathrm{D}(2)$ & - & $\mathrm{D}(2)$ & + & - & + & + & + & + & + & - & - & + & - & - \\
\hline \multicolumn{19}{|l|}{ Assimilation of: $\downarrow$} \\
\hline Adonitol & - & - & - & - & - & + & $\mathrm{D}(1)$ & $\mathrm{D}(1)$ & - & + & - & - & - & - & - & - & - & - \\
\hline Erythritol & - & - & - & - & - & $\mathrm{D}(2)$ & + & - & - & + & - & - & - & - & - & - & - & - \\
\hline Mannitol & - & - & - & - & - & $\mathrm{D}(2)$ & + & - & - & + & - & - & - & - & - & - & - & - \\
\hline Sorbitol & + & + & + & - & + & + & + & + & - & + & - & + & - & + & - & - & - & - \\
\hline \multicolumn{19}{|l|}{ Oxidation of: $\S$} \\
\hline$p$-Hydroxy phenylacetic acid & + & + & + & + & - & $\mathrm{D}(2)$ & $\mathrm{D}(2)$ & + & + & - & + & + & + & - & + & + & - & + \\
\hline Itaconic acid & - & - & $\mathrm{D}(1)$ & - & $\mathrm{D}(1)$ & + & + & + & - & + & + & + & + & - & - & - & + & + \\
\hline$\gamma$-Hydroxybutyric acid & + & + & + & $\mathrm{D}(1)$ & - & - & $\mathrm{D}(1)$ & - & - & - & - & - & - & - & - & - & + & - \\
\hline Glucuronamide & - & $\mathrm{D}(3)$ & $\mathrm{D}(1)$ & + & $\mathrm{D}(2)$ & + & + & $\mathrm{D}(1)$ & + & + & - & - & - & - & + & + & - & - \\
\hline Succinamic acid & + & - & + & $\mathrm{D}(3)$ & + & + & + & + & - & + & + & + & + & + & + & - & + & + \\
\hline
\end{tabular}

* Species in each phenon or subphenon: subphenon 1a, $P$. brassicacearum $(n=7)$; subphenon $1 \mathrm{~b}, P$. thivervalensis $(n=6)$; subphenon 1c, $P$. brassicacearum $(n=3)$; phenon 2, $P$. corrugata $(n=4)$; phenon $3, P$. fluorescens $(n=3)$; phenon 4 , $P$. fluorescens $(n=3)$; phenon 5, P. marginalis $(n=3)$; phenon 6, P. fluorescens $/ P$. putida $(n=2)$.

$\dagger$ Pseudomonas type strains are: P. asplenii CFBP $3279^{\mathrm{T}}$, P. tolaasii CFBP 2068 ${ }^{\mathrm{T}}$, P. aureofaciens CFBP $2133^{\mathrm{T}}$, P. chlororaphis CFBP


and P. flectens CFBP $3281^{\mathrm{T}}$.

$\$$ Biotype 100 substrates.

$\S$ Biolog substrates.

$1 \mathrm{a}, 1 \mathrm{~b}$ and $1 \mathrm{c}$. Phenon 1 is phenotypically related to phenon 2, which contains P. corrugata strains, and can be differentiated by two characters: production of levan and assimilation of sorbitol (Table 2). However, phenon 1 can be clearly differentiated from the other phenons (3-6) and from the type strains of major fluorescent, oxidase-positive Pseudomonas species by several biochemical characters (Table 2). The biochemical character that allows discrimination of subphenons $1 \mathrm{a}, 1 \mathrm{~b}$ and $1 \mathrm{c}$ is the oxidation of succinamic acid. On the basis of additional results obtained with Biotype 100 strips (data not shown), none of the 99 assimilation tests was found to discriminate among subphenons $1 \mathrm{a}, 1 \mathrm{~b}$ and $1 \mathrm{c}$.

\section{ARDRA}

The PCR products of the rrs gene of the 16 rootassociated strains of phenon 1 and of the type strains of 20 Pseudomonas species, including $P$. corrugata (listed in Methods) were mapped with 11 restriction enzymes (ARDRA). The 16 root-associated strains of phenon 1 provided exactly the same profile with the restriction enzymes tested and belonged to a single ARDRA group. They showed differences with at least two restriction enzymes from the type strains of the 19 Pseudomonas species analysed and only TaqI enzyme could discriminate them from the type strain of $P$. corrugata.

\section{rrs gene sequence analysis}

Results of phylogenetic analysis clearly showed that the three strains CFBP $11706^{\mathrm{T}}$, CFBP $11261^{\mathrm{T}}$ and CFBP 11874, which belong to subphenons $1 \mathrm{a}, 1 \mathrm{~b}$ and 1c, respectively, of phenon 1 (Fig. 1), should be included in the true genus Pseudomonas (data not shown). To obtain a precise phylogenetic identification, analyses were thus restricted to members of this taxon, including one sequence for each validated Pseudomonas species and the rrs gene sequence of the root-associated strains. All three phylogenetic analyses (neighbour-joining, parsimony, maximum-likelihood) showed that the three rhizoplane strains formed a robust monophyletic unit (Fig. 2). Strains CFBP $11706^{\mathrm{T}}$, CFBP $11261^{\mathrm{T}}, \mathrm{CFBP} 11874$ and P. corrugata formed a clade identified by all three methods that showed a high bootstrap percentage $(90 \%)$. rrs sequence similarities were: $99 \cdot 8 \%$ for CFBP $11706^{\mathrm{T}}$ and CFBP $11874 ; 99 \cdot 3 \%$ for CFBP $11706^{\mathrm{T}}$ and CFBP $11261^{\mathrm{T}} ; 99 \cdot 5 \%$ for CFBP $11261^{\mathrm{T}}$ and CFBP 11874 ; $99 \cdot 1 \%$ for CFBP $11706^{\mathrm{T}}$ and P. corrugata ATCC $29736^{\mathrm{T}}$; and $99 \cdot 2 \%$ for CFBP $11261^{\mathrm{T}}$ and ATCC $29736^{\mathrm{T}}$.

\section{DNA-DNA hybridization}

Labelled DNA of strains CFBP $11261^{\mathrm{T}}$, CFBP 11699 and CFBP $2431^{\mathrm{T}}$ was hybridized to DNA of strains of 


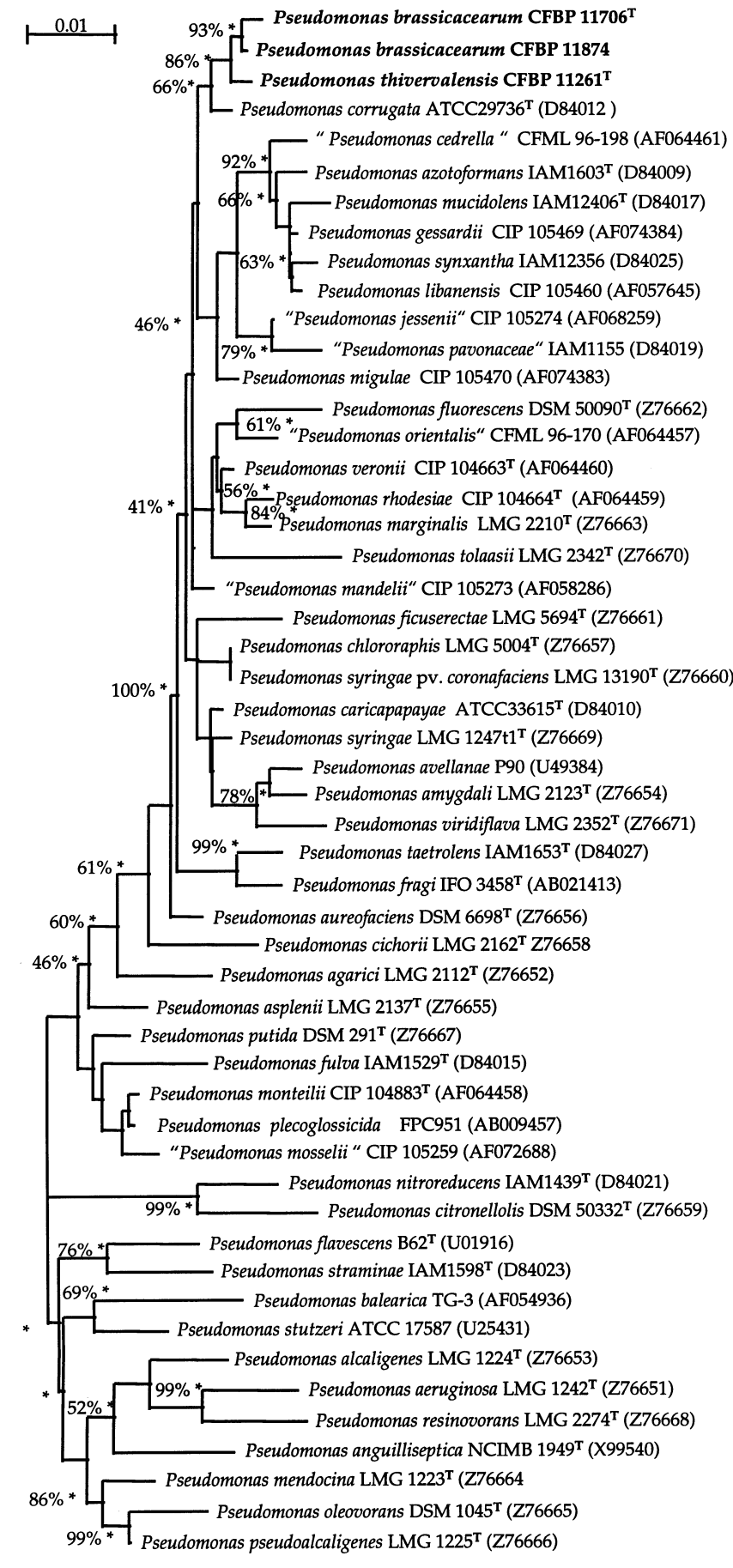

Fig. 2. Unrooted phylogenetic tree of Pseudomonas $16 \mathrm{~S}$ rDNA sequences. This topology was obtained using all known complete or almost complete sequences from Pseudomonas strains. The topology was obtained by neighbour-joining (Kimura two-parameters, percentage of 500 bootstrap replications shown by major branches). Asterisks indicate clades also found by maximum-likelihood $(P<0.01)$ and in the most parsimonious tree. Bar, 1 base substitution per 100 nucleotide positions.

phenon 1 and of type strains of 15 related Pseudomonas species or unnamed genomospecies FP1, FP2 and FP3 (Sutra et al., 1997) (Table 3). Strains of subphenons 1a and 1c showed 70-99\% DNA relatedness with strain CFBP 11699 and strains of subphenon $1 \mathrm{~b}$ showed $73-87 \%$ DNA relatedness with strain CFBP $11261^{\mathrm{T}}$. Levels of similarity observed between strains of subphenons 1a and 1c and strain CFBP $11261^{\mathrm{T}}$ were $50-62 \%$ and those between strains of subphenon $1 \mathrm{~b}$ and strain CFBP 11699 were 53-59\%. However, $\Delta T_{\mathrm{m}}$ values were greater than $5{ }^{\circ} \mathrm{C}\left(5 \cdot 7-7 \cdot 5^{\circ} \mathrm{C}\right)$ (Table 3$)$.

The levels of DNA relatedness of strain CFBP 11699 with the type strains of the 15 Pseudomonas species and genomospecies tested ranged from $9 \%$ with $P$. aeruginosa CFBP $2466^{\mathrm{T}}$ to $39 \%$ with strain CFBP 10529 of genomospecies FP1, whereas the levels of DNA relatedness of strain CFBP $11261^{\mathrm{T}}$ ranged from $10 \%$ with $P$. aeruginosa CFBP $2466^{\mathrm{T}}$ to $47 \%$ with strain CFBP 10530 of genomospecies FP2. Levels of similarity observed with $P$. corrugata type strain CFBP $2431^{\mathrm{T}}$ were $33 \%$ for strain CFBP 11699 and $34 \%$ for strain CFBP $11261^{\mathrm{T}}$. Moreover, the percentages of hybridization of labelled DNA of $P$. corrugata type strain CFBP $2431^{\mathrm{T}}$ with strains CFBP 11267 and CFBP 11268 (subphenon 1a) and strain CFBP 11261 (subphenon 1b) were 48,45 and $46 \%$, respectively (Table 3).

\section{DNA base composition}

The DNA G + C content of strains CFBP 11699 and CFBP $11261^{\mathrm{T}}$ was $60 \cdot 8 \mathrm{~mol} \%$.

\section{Siderotyping}

Strains belonging to subphenon $1 \mathrm{~b}$ displayed an identical IEF pattern for the pyoverdines they produced during growth on CAA medium. The three bands observed for each strain of subphenon $1 \mathrm{~b}$ were characterized by $\mathrm{pI}$ values of $7 \cdot 5,7 \cdot 2$ and $5 \cdot 7$, respectively (Fig. 3). In contrast, a single band with a $\mathrm{pI}$ of 4.0 was detected for strains belonging to subphenons 1a and 1c (Fig. 3). However, electrophoresis on Cellogel revealed three well-separated pyoverdine spots (data not shown), suggesting that the different forms (see Discussion) of the pyoverdine from phenon 1a and $1 \mathrm{c}$ were concentrated in a single IEF band, the migration of which was at the limit of the acid front of the $\mathrm{pH}$ gradient. No pyoverdine production was observed with $P$. corrugata CFBP $2431^{\mathrm{T}}$.

\section{Colony morphology and phenotypic variations}

At least two different colony types were observed with strains belonging to the two groups (subphenons $1 \mathrm{a} / 1 \mathrm{c}$ and $1 \mathrm{~b}$ ) at stationary phase when grown on rich media such as LB and King B. Variants from these two groups of strains showed fluorescent pigmentation on King B medium, unlike the original isolates. The variants also showed variable characteristics for reduction of nitrate, presence of gelatinase and hydrolysis of Tween 80 . 
Table 3. Results of DNA-DNA hybridization experiments

NT, Not tested; IS, isolated strains.

\begin{tabular}{|c|c|c|c|c|}
\hline \multirow[t]{2}{*}{ Source of unlabelled DNA } & \multirow{2}{*}{$\begin{array}{c}\text { Phenon, subphenon } \\
\text { or isolated strain }\end{array}$} & \multicolumn{3}{|c|}{ Reassociation (\%) with labelled DNA from strains:* } \\
\hline & & $\begin{array}{l}\text { P. brassicacearum } \\
\text { CFBP } 11699\end{array}$ & $\begin{array}{c}\text { P. thivervalensis } \\
\text { CFBP } 11261^{\mathrm{T}}\end{array}$ & $\begin{array}{l}\text { P. corrugata } \\
{\text { CFBP } 2431^{\mathrm{T}}}^{\text {CFB }}\end{array}$ \\
\hline \multicolumn{5}{|l|}{ P. brassicacearum } \\
\hline CFBP 11264 & 1a & 98 & 62 & NT \\
\hline CFBP 11711 & $1 \mathrm{a}$ & 81 & 59 & NT \\
\hline CFBP 11267 & $1 \mathrm{a}$ & 89 & 50 & 48 \\
\hline CFBP 11268 & $1 \mathrm{a}$ & 99 & 60 & 45 \\
\hline CFBP 11700 & $1 \mathrm{a}$ & 89 & 60 & NT \\
\hline CFBP 11699 & $1 \mathrm{a}$ & 100 & $53(5 \cdot 7)$ & NT \\
\hline CFBP $11706^{\mathrm{T}}$ & $1 \mathrm{a}$ & 96 & $61(6 \cdot 1)$ & NT \\
\hline CFBP 11875 & $1 \mathrm{c}$ & 95 & 53 & NT \\
\hline CFBP 11874 & $1 \mathrm{c}$ & 70 & 50 & NT \\
\hline CFBP 11862 & $1 \mathrm{c}$ & 86 & 58 & NT \\
\hline \multicolumn{5}{|l|}{ P. thivervalensis } \\
\hline CFBP 11866 & $1 b$ & $58(6 \cdot 7)$ & 77 & NT \\
\hline CFBP 11864 & $1 b$ & 59 & 82 & NT \\
\hline CFBP $11261^{\mathrm{T}}$ & $1 b$ & $56(7 \cdot 5)$ & 100 & 46 \\
\hline CFBP 11863 & $1 b$ & 53 & 73 & NT \\
\hline CFBP 11867 & $1 b$ & 57 & 87 & NT \\
\hline CFBP 11865 & $1 b$ & 59 & 86 & NT \\
\hline \multicolumn{5}{|l|}{ Type strains } \\
\hline P. aeruginosa $\mathrm{CFBP} 2466^{\mathrm{T}}$ & IS & 9 & 10 & NT \\
\hline P. agarici CFBP $2063^{\mathrm{T}}$ & IS & 17 & 15 & NT \\
\hline P. asplenii CFBP $3279^{\mathrm{T}}$ & IS & 30 & NT & NT \\
\hline P. aureofaciens CFBP $2133^{\mathrm{T}}$ & IS & 27 & 23 & NT \\
\hline P. chlororaphis $\mathrm{CFBP} 2132^{\mathrm{T}}$ & IS & 25 & 23 & NT \\
\hline P. cichorii CFBP $2101^{\mathrm{T}}$ & IS & 10 & 10 & NT \\
\hline P. corrugata CFBP $2431^{\mathrm{T}}$ & 2 & 33 & 34 & 100 \\
\hline P. fluorescens CFBP $2102^{\mathrm{T}}$ & 4 & 16 & 18 & NT \\
\hline P. fuscovaginae CFBP $2065^{\mathrm{T}}$ & IS & 20 & 17 & NT \\
\hline P. marginalis CFBP $1387^{\mathrm{T}}$ & NT & NT & 22 & NT \\
\hline P. putida CFBP $2066^{\mathrm{T}}$ & IS & 13 & 17 & NT \\
\hline P. tolaasii CFBP $2068^{\mathrm{T}}$ & IS & 24 & 20 & NT \\
\hline Genomospecies FP1 CFBP $10529^{\mathrm{T}}$ & NT & 39 & 44 & NT \\
\hline Genomospecies FP2 CFBP $10530^{\mathrm{T}}$ & NT & 29 & 47 & NT \\
\hline Genomospecies FP3 CFBP $10569^{\mathrm{T}}$ & NT & 13 & 21 & NT \\
\hline
\end{tabular}

* Values in parentheses are values of $\Delta T_{\mathrm{m}}$ in degrees Celsius.

\section{DISCUSSION}

On the basis of phenotypic data, Pseudomonas strains isolated from the rhizoplane of $A$. thaliana and $B$. napus clustered in a single phenon (phenon 1). All the strains were oxidase-positive, non-pectinolytic and produced levan. They produced DNase, arginine dihydrolase, and hydrolysed Tween 80 and gelatin but not aesculin. These general characteristics correspond to the characteristics of the LOPAT group Va in the determinative scheme for the fluorescent pathogenic pseudomonads of Leliott et al. (1966), which also includes saprophytic fluorescent Pseudomonas species, such as $P$. fluorescens, which are usual inhabitants of the rhizosphere of plants. Phenon 1 is phenotypically related to phenon 2 which contains $P$. corrugata strains and can be differentiated by three characters: production of pyoverdine, production of levan and assimilation of sorbitol. Strains included in phenon 1 were phenotypically variable and distributed into three subphenons $1 \mathrm{a}, 1 \mathrm{~b}$ and $1 \mathrm{c}$. The two groups corresponding to subphenons $1 \mathrm{a}$ and $1 \mathrm{c}$, and to subphenon $1 \mathrm{~b}$, respectively, can be distinguished by the assimilation of succinamic acid and, as shown in this work, by the production of different types of pyoverdine. With respect to rrs gene sequence analysis, strains clustered in subphenons $1 \mathrm{a}, 1 \mathrm{~b}$ and 1c were closely related to $P$. corrugata $(99 \cdot 1 \%$ homology). ARDRA 




(a)

(b)

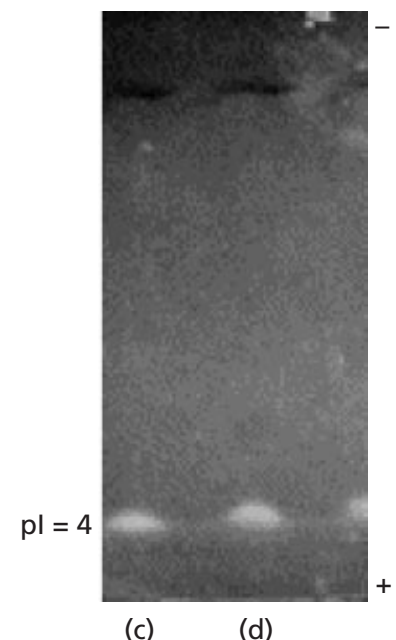

(c) (d)
Fig. 3. Isoelectric focusing of pyoverdines from $P$. thivervalensis CFBP $11261^{\top}$ (a) and CFBP 11866 (b), and P. brassicacearum CFBP 11711 (c) and CFBP 11874 (d).

discriminated among subphenons $1 \mathrm{a}, 1 \mathrm{~b}$ and $1 \mathrm{c}$ from $P$. corrugata when TaqI restriction enzyme was used, but failed to discriminate among isolates within these three subphenons. However, results of DNA-DNA hybridizations clearly indicated that subphenons 1a/1c and subphenon $1 \mathrm{~b}$ belong to two discrete but closely related genomospecies, which are different from both $P$. corrugata and the other fluorescent Pseudomonas species tested. The DNA G $+\mathrm{C}$ contents of these two new genomospecies $(60.8 \mathrm{~mol} \%)$ fell within the range of G + C contents of the genus Pseudomonas (55.2-67.2 mol \%) (De Vos et al., 1989; Palleroni, 1984).

Intraclonal phenotypic variation is common in pseudomonads (Adams \& Pugsley, 1934; Kelman, 1954) and has been reported recently for P. tolaasii (Grewal \& Rainey, 1991) and P. corrugata (Siverio et al., 1993) isolates. It results in morphologically distinct colony types originating from the same bacterial clone. In this study, strains from $A$. thaliana and B. napus rhizoplane, which were non-fluorescent at primary isolation, produced fluorescent variants when cultured on King B medium. The fluorescent variants appeared at the edge of non-fluorescent colonies at late stationary phase. Variants also showed variations for reduction of nitrate and hydrolysis of gelatin and Tween 80 that were different from those of the initial non-fluorescent isolates. However, pyoverdine production was identical in initial and variant strains. The role of this phenotypic variation in the ability of strains to adapt to the rhizoplane is being investigated.

In this study, the pyoverdine typing performed by IEF proved to be a powerful technique for species discrimination. Strains belonging to subphenon $1 \mathrm{~b}$ were characterized by a single siderotype consisting of three bands with different pI values. These bands may correspond to pyoverdine forms differing in the nature of the side-chain (succinamide, succinate, 2-oxoglutarate, etc.) attached to the chromophore of the molecule (Budzikiewicz, 1993; Meyer et al., 1997). For strains of subphenons la and 1c, a single IEF pattern, which was different from that of strains of subphenon $1 \mathrm{~b}$, was observed. An IEF-pyoverdine typing of an extended collection of bacteria is being investigated to assess the use of the method for taxonomic purposes among the fluorescent Pseudomonas species.

On the basis of phenotypic properties, DNA-DNA reassociation values, $r r s$ gene sequencing and siderophore typing, strains included in subphenons la and $1 \mathrm{c}$, and strains included in subphenon $1 \mathrm{~b}$ should be considered as two new Pseudomonas species. The names Pseudomonas brassicacearum sp. nov. and Pseudomonas thivervalensis sp. nov. are proposed.

\section{Description of Pseudomonas brassicacearum sp. nov.}

Pseudomonas brassicacearum (bras.si.ca.ce.a'rum. M. L. fem. pl. gen. n. brassicacearum of the Brassicaceae, referring to its isolation from the rhizoplane of plants belonging to the Brassicaceae).

The studied strains belong to a larger collection of isolates that belong to the species $P$. brassicacearum. They were isolated from the rhizoplane of $A$. thaliana and $B$. napus growing on different soils. They represent more than $10 \%$ of total cultivated bacteria associated with the roots of these plants (unpublished data). Gram-negative motile rods, $1.0-1.5 \mu \mathrm{m}$ in length, about $0.5 \mu \mathrm{m}$ in diameter. Forms mucoid colonies with regular margins when grown on TSA and produces brown-orange diffusible pigment at late stationary phase on TSA and in TSB, but not on these media when diluted tenfold. Can also produce a fluorescent pigment when grown on CAA medium. Aerobic growth, oxidase-positive, arginine dihydrolase-positive, produces levan, not pectinolytic. Reduction of nitrate to nitrite is variable. Hydrolyses gelatin, DNA and Tween 80 but not aesculin. Produces no hypersensitivity reaction on tobacco leaves. Acid produced from sucrose and sorbitol but not from erythritol and mannitol. Results obtained with BIOLOG GN microplates indicate that strains oxidize the following substrates: acetic acid, $N$-acetylglucosamine, alaninamide, D-alanine, L-alanine, L-alanyl-glycine, $\gamma$-aminobutyric acid, 2-aminoethanol, L-arabinose, D-arabitol, L-asparagine, L-aspartic acid, cis-aconitic acid, bromosuccinic acid, DL-carnitine, citric acid, formic acid, D-fructose, D-galactonic acid lactone, D-galactose, D-galacturonic acid, $\alpha$-D-glucose, D-gluconic acid, D-glucosaminic acid, D-glucuronic acid, L-glutamic acid, glycerol, L-histidine, $\beta$-hydroxybutyric acid, $\gamma$-hydroxybutyric acid, $p$-hydroxyphenyl acetic acid, hydroxy-L-proline, inosine, $m$-inositol, $\alpha$-ketoglutaric acid, DL-lactic acid, malonic acid, D-mannitol, D-mannose, methylpyruvate, monomethylsuccinate, L-ornithine, L-proline, propionic acid, L-pyroglutamic acid, quinic acid, D-saccharic acid, sebacic acid, L-serine, D-sorbitol, succinamic acid, succinic acid, 
sucrose, D-trehalose, L-threonine, Tween 40, Tween 80 , uridine and urocanic acid. Oxidation of 2,3-butanediol, DL- $\alpha$-glycerol phosphate, glycyl L-glutamic acid, $\alpha$-hydroxybutyric acid, $\alpha$-ketobutyric acid, $\alpha$-ketovaleric acid, L-leucine, maltose, psicose and turanose is variable. Oxidation of the other organic substrates included in BIOLOG GN microplates is negative. $P$. brassicacearum strains assimilate the following substrates (Biotype 100 strips): $N$-acetyl-D-glucosamine, cis-aconitate, trans-aconitate, D-alanine, L-alanine, DL- $\alpha$-amino-n-butyrate, DL- $\alpha$-amino-n-valerate, L-arabinose, D-arabitol, L-aspartate, betaine, caprate, caprylate, citrate, ethanolamine, $\beta$-D-fructose, fumarate, D-galactose, D-galacturonate, D-gluconate, D-glucosamine, $\alpha$-D-glucose, D-glucuronate, L-glutamate, glutarate, DL-glycerate, glycerol, 2-keto-D-gluconate, 2 -oxoglutarate, DL- $\beta$-hydroxybutyrate, $p$-hydroxybenzoate, DL-lactate, D-lyxose, L-malate, D-mannose, D-mannitol, mucate, myo-inositol, L-proline, propionate, protocatechuate, quinate, D-ribose, D-saccharate, L-serine, D-sorbitol, succinate, sucrose, D-trehalose, trigonelline, L-tyrosine and D-xylose. Assimilation of benzoate, $\mathrm{D}(+)$ malate, malonate, putrescine and $\mathrm{D}(-)$ tartrate is variable. The other organic substrates included in Biotype 100 strips are not assimilated. DNA $\mathrm{G}+\mathrm{C}$ content is $60.8 \mathrm{~mol} \%$. Type strain is strain DBK $11^{\mathrm{T}}$ which has been deposited in the Collection Française de Bactéries Phytopathogènes (CFBP, Angers, France) under the number CFBP $11706^{\mathrm{T}}$.

\section{Description of Pseudomonas thivervalensis sp. nov.}

Pseudomonas thivervalensis (thi.ver.va.len'sis. M.L. adj. thivervalensis pertaining to Thiverval, France, the place where most of the strains have been isolated from the rhizoplane of Arabidopsis thaliana).

Gram-negative motile rods, $1.0-1.5 \mu \mathrm{m}$ in length, about $0.5 \mu \mathrm{m}$ in diameter. Forms mucoid colonies with regular margins when grown on TSA and produces brown-orange diffusible pigment at late stationary phase on TSA and in TSB, but not on these media when diluted tenfold. They can also produce a fluorescent pigment when grown on CAA medium. $P$. thivervalensis has the same general characteristics as $P$. brassicacearum. Oxidation of the following substrates is variable: D-galacturonic acid, glucuronamide, D-glucuronic acid, L-ornithine, putrescine and L-threonine. Unlike $P$. brassicacearum, $P$. thivervalensis strains do not oxidize succinamic acid. $P$. thivervalensis strains do not assimilate benzoate unlike $80 \%$ of $P$. brassicacearum strains. The oxidation and the assimilation of the other organic substrates tested with BIOLOG GN microplates and with Biotype 100 strips are the same for strains of $P$. thivervalensis as for $P$. brassicacearum strains (see above). DNA G + C content is $60.8 \mathrm{~mol} \%$. The type strain is strain SBK $26^{\mathrm{T}}$, which has been deposited in the Collection Française de Bactéries Phytopathogènes (CFBP) under number CFBP $11261^{\mathrm{T}}$.

\section{ACKNOWLEDGEMENTS}

We thank S. Belouin for technical assistance and A. Huard for designing the dendrogram of phenotypical distances.

\section{REFERENCES}

Achouak, W., Christen, R., Barakat, M., Martel, M. H. \& Heulin, T. (1999). Burkholderia caribensis sp. nov., exopolysaccharideproducing bacteria isolated from vertisol microaggregates in Martinique. Int J Syst Bacteriol 49, 787-794.

Adams, D. B. \& Pugsley, A. T. (1934). 'Smooth-rough' variation in Phytomonas medicagenis phaseolitica Burk. Aust J Exp Biol Med Sci 12, 193-202.

Anderson, R. D., Bao, C.-Y., Minnick, D. T., Veigel, M. \& Sedwick, W. D. (1992). Optimization of double-stranded DNA sequencing for polymerase chain reaction products. USB Editorial Comments 19, 39-40, 57-58.

Ayers, S. H., Rupp, P. \& Johnson, W. T. (1919). A study of alkaliforming bacteria in milk. USDA Bulletin no. 782.

Behrendt, U., Ulrich, A., Schumann, P., Erler, W. \& Seyfarth, W. (1999). Taxonomic study of bacteria isolated from grasses: proposal of Pseudomonas graminis sp. nov. Int J Syst Bacteriol 49, 297-308.

Boivin-Jahns, V., Bianchi, A., Ruimy, R., Garcin, J., Daumas, S. \& Christen, R. (1995). Comparison of phenotypical and molecular methods for the identification of bacterial strains isolated from a deep subsurface environment. Appl Environ Microbiol 61, 3400-3406.

Brenner, D. J., McWorter, A. C., Leete Knutson, J. K. \& Steigerwalt, A. G. (1982). Escherichia vulneris: a new species of Enterobacteriaceae associated with human wounds. J Clin Microbiol 15, 1133-1140.

Budzikiewicz, H. (1993). Secondary metabolites from fluorescent pseudomonads. FEMS Microbiol Rev 104, 209-228.

Croza, J. M., Brenner, D. J. \& Falkow, S. (1973). Use of a singlestranded-specific nuclease for analysis of bacterial and plasmid deoxynucleic acid homo- and heteroduplex. J Bacteriol 115, 904-911.

Descamps, P. \& Véron, M. (1981). Une méthode de choix des caractères d'identification basée sur le théorème de Bayes et la mesure de l'information. Ann Inst Pasteur Microbiol 132B, 157-170.

De Vos, P., Van Landshoot, A., Segers, P. \& 9 other authors (1989). Genotypic relationship and taxonomic localization of unclassified Pseudomonas and Pseudomonas-like strains by deoxyribonucleic acid-ribosomal ribonucleic acid hybridization. Int J Syst Bacteriol 39, 35-49.

Gould, W. D., Hagedorn, C., Bardinelli, T. R. \& Zablotowicz, R. M. (1985). New selective media for enumeration and recovery of fluorescent Pseudomonads from various habitats. Appl Environ Microbiol 49, 28-32.

Grewal, S. I. S. \& Rainey, P. B. (1991). Phenotypic variation of Pseudomonas putida and Pseudomonas tolaasii affects the chemotactic response to Agaricus bisporus mycelium. J Gen Microbiol 137, 2761-2768.

Grimont, P. A. D., Popoff, M. Y., Grimont F., Coynault, C. \& Lemelin, M. (1980). Reproducibility and correlation study of three deoxynucleic acid hybridization procedures. Curr Microbiol 4, 325-330.

Heulin, T., Guckert, A. \& Balandreau, J. (1987). Stimulation of root exudation of rice seedlings by Azospirillum strains: carbon budget under gnotobiotic conditions. Biol Fertil Soils 4, 9-14. 
Hildebrand, D. C. (1971). Pectate and pectin gels for differentiation of Pseudomonas sp. and other bacterial plant pathogens. Phytopathology 61, 1430-1436.

Kelman, A. (1954). The relationship of pathogenicity in Pseudomonas solanacearum to colony appearance on a tetrazolium medium. Phytopathology 44, 693-695.

Kersters, K., Ludwig, W., Vancanneyt, M., De Vos, P., Gillis, M. \& Schleifer, K. H. (1996). Recent changes in the classification of the pseudomonads: an overview. Syst Appl Microbiol 19, 465-477.

Koedam, N., Wittouck, E., Gaballa, A., Gillis, A., Höfte, M. \& Cornelis, P. (1994). Detection and differentiation of microbial siderophores by isoelectric focusing and chrome azurol S overlay. Biometals 7, 287-291.

Laguerre, G., Rigottier-Gois, L. \& Lemanceau, P. (1994). Fluorescent Pseudomonas species categorized by using polymerase chain reaction $(\mathrm{PCR}) /$ restriction fragment analysis of $16 \mathrm{~S}$ rDNA. Mol Ecol 3, 479-487.

Leliott, R. A., Billing, E. \& Hayward, A. C. (1966). A determinative scheme for the fluorescent plant pathogenic pseudomonads. $J$ Appl Bacteriol 29, 470-489.

Marmur, J. \& Doty, P. (1962). Determination of the base composition of deoxyribonucleic acid from its thermal denaturation temperature. J Mol Biol 5, 109-118.

Mavingui, P., Laguerre, G., Berge, O. \& Heulin, T. (1992). Genetic and phenotypic diversity of Bacillus polymyxa in soil and in the wheat rhizosphere. Appl Environ Microbiol 58, 1894-1903.

Meyer, J. M. \& Abdallah, M. A. (1978). The fluorescent pigment of Pseudomonas fluorescens: biosynthesis, purification and physicochemical properties. J Gen Microbiol 107, 319-328.

Meyer, J. M., Stintzi, A., De Vos, D., Cornelis, P., Tappe, R., Taraz, K. \& Budzikiewicz, H. (1997). Use of siderophores to type pseudomonads: the three Pseudomonas aeruginosa pyoverdine systems. Microbiology 143, 35-43.

Owen, R. J. \& Lapage, S. P. (1976). The thermal denaturation of partly purified bacterial deoxyribonucleic acid and its taxonomic implications. J Appl Bacteriol 41, 335-340.

Palleroni, N. J. (1984). Genus I. Pseudomonas Migula 1894. In Bergey's Manual of Systematic Bacteriology, vol. 1, pp. 141-199. Edited by N. R. Krieg \& J. G. Holt. Baltimore: Williams \& Wilkins.
Palleroni, N. J., Kunisawa, R., Contopoulou, R. \& Doudoroff, M. (1973). Nucleic acid homologies in the genus Pseudomonas. Int J Syst Bacteriol 23, 333-339.

Prunier, J. P. \& Kaiser, P. (1964). Etude de l'activité pectinolytique chez des bactéries phytopathogènes et saprophytes des plantes. I. Recherche des enzymes pectinolytiques. Ann Epiphyt (Paris) 15, 205-209.

Rhodes, M. E. (1958). The cytology of Pseudomonas spp. as revealed by silver-plating staining method. J Gen Microbiol 18, 639-648.

Saitou, N. \& Nei, M. (1987). The Neighbor-Joining method: a new method for reconstructing phylogenetic trees. Mol Biol Evol 4, 406-425.

Siverio, F., Cambra, M., Gorris, M. T., Corso, J. \& Lopez, M. M. (1993). Lipopolysaccharides as determinants of serological variability in Pseudomonas corrugata. Appl Environ Microbiol 59, 1805-1812.

Skerman, V. B. D., McGowan, V. \& Sneath, P. H. A. (1989). Approved Lists of Bacterial Names. Washington, DC: American Society for Microbiology.

Sneath, P. H. A. \& Sokal, R. R. (1973). Numerical Taxonomy: the Principles and Practice of Numerical Classification. San Francisco: W. H. Freeman.

Sutra, L., Siverio, F., Lopez, M. M., Hunault, G., Bollet, C. \& Gardan, L. (1997). Taxonomy of Pseudomonas strains isolated from tomato pith necrosis: emended description of Pseudomonas corrugata and proposal of three unnamed fluorescent Pseudomonas genomospecies. Int J Syst Bacteriol 47, $1020-1033$

Swofford, D. (1990). PAUP: phylogenetic analysis using parsimony, version 3.0. Computer program distributed by the Illinois Natural History Survey, Champaign, Illinois, USA.

Whyte, L. G., Bourbonniere, L. \& Greer, C. W. (1997). Biodegradation of petroleum hydrocarbons by psychrophilic Pseudomonas strains possessing both alkane (alk) and naphthalene (nah) catabolic pathways. Appl Environ Microbiol 63, 3719-3723.

Wilson, A. E., Moore, E. R. \& Mohn, W. W. (1996). Isolation and characterization of isopimaric acid-degrading bacteria from a sequencing batch reactor. Appl Environ Microbiol 62, $3146-3151$. 